UDC 621.391

\title{
INCREASING THE WIRELESS SYSTEMS INFORMATION EFFICIENCY USING LDPC CODING
}

\author{
Leonid O. Uryvsky, Alina V. Moshynska, Serhii O. Osypchuk \\ Institute of Telecommunication Systems \\ Igor Sikorsky Kyiv Politechnic Institute, Kyiv, Ukraine
}

\begin{abstract}
Background. LDPC codes research is performed in the paper. The influence of LDPC codes on channel information efficiency is studied in scope of MCS and the benefit of using LDPC codes is specified in digits as a result of research.

Objective. The purpose of the paper is LDPC correcting abilities research in modern telecom systems and their comparison to other known error-correcting codes, and research of their influence on information efficiency of telecommunication system.

Methods. Simulation modeling algorithm is implemented in Matlab using Java language, what helps generating corrective matrices and allows us to find out the corrective abilities of LDPC codes with different set of parameters. Many experiments make a statistic that shows a maximum and the best corrective abilities of LDPC codes, what is the aim of applying the simulation modeling approach.

Results. The programmable simulation models to generate LDPC codes and errors number determining corrected LDPC codes with different parameters are developed. It's the first time the method is proposed of determining the ultra-long block LDPC codes to ensure the reliability characteristics specified in the channel with known parameters, characterized in that the analysis parameters LDPC code is implemented using the original statistical model and to evaluate corrective ability to code at a significant increase in the length of the block LDPC code. Also, the LDPC codes influence on channel information efficiency is researched, and shown $9 . . .52 \%$ improvement.

Conclusions. The important scientific problem is solved in the paper, - construction and use of advanced wireless transmission systems with increasing information efficiency using LDPC coding. Stages of channel resources redistribution include LDPC, OFDM, modulation, described and presented in the information efficiency coordinates and transmission system performance.
\end{abstract}

Keywords: information efficiency; channel resources; low density parity check codes (LDPC); modulation-coding schemes (MCS).

\section{Introduction}

Wireless transmission systems occupy a significant part of the global telecommunications space. Voice, data, video streaming and other services is an integral part of services provided by the wireless communication systems. Any wireless transmission system uses the limited resources link: power, frequency, time. Number of users of wireless transmission systems is growing, while wireless channel resources are limited.

The most significant features of the advanced and emerging wireless communication systems is the use of ultra-long redundant block noise immune LDPC codes (low density parity check) to provide a necessary reliability, - that distinguishes them from the means of previous generations wireless transmission systems [12]. Modulation and coding types are combined into modulation-coding schemes (MCS), allowing a high data rate transmission for each user, with needed information transmission reliability, and the maximum wireless transmission systems information efficiency.

Many papers are already devoted to LDPC codes research [3-9]. The task of current study is to develop a method of ultra-long block codes parameters control to ensure the needed performance reliability. The research object is the information efficiency of wireless transmission systems. The research subject is the performance improvement of wireless communication systems based on the use of noise immune block LDPC codes.

Scientific novelty of the results is the following: the parameters determination method of ultra-long block LDPC codes to provide the specified reliability characteristics in channel with known parameters. This method is characterized by the original statistical model to evaluate a corrective ability of LDPC codes when increasing the length of LDPC block codes significantly.

\section{Information efficiency of communication channel}

The assumption thesis of the research is that a certain set of frequency and power resources are needed to send information over a wireless communication channel on the same frequency with a given speed and reliability. The study conditions for reallocation of frequency and 
energy resources remain unchanged while maintaining the requirements for reliability and transmission speed.

To restore the needed information reliability, the ultra-long block LDPC codes are proposed to use, as one of the most effective means of improving the information transmission reliability. Codes are called as ultra-long if the length of block exceeds several thousand bits as opposed to common codes (e.g., BCH) with thousands of bits per block.

Thus, the strategy comes from the study of the latest trends in wireless communications, entrusted with the task of maximizing the amount of information transmitted with high reliability to a large users number. To implement this strategy, the use of ultra-long LDPC codes is discovered, typical for technical solutions to wireless communication systems the fourth and fifth generations.

The resources efficiency usage measure is transmitted information amount that relates to channel resource unit. Accordingly, channel resources efficiency usage assessment are following; frequency efficiency, energy efficiency and information efficiency.

Frequency efficiency $\gamma$ (1) shows the information amount transmitted per frequency resource unit $\Delta F$ :

$$
\gamma=\frac{R_{\mathrm{d}}}{\Delta F}
$$

Energy efficiency $\beta$ (2) shows the information amount $R_{d}$ transmitted per energy source unit $\alpha$ :

$$
\beta=\frac{R_{\mathrm{d}}}{\alpha}=\frac{R_{\mathrm{d}} \cdot N_{0}}{P_{\mathrm{RX}}},
$$

where $\alpha=P_{R X} / N_{0}$ - the ratio of signal power to the spectral density noise power at the admission point; $P_{R X}=x \cdot P_{T X}$, where $P_{T X}-$ the transmitter signal level, $0<x<1$.

Information efficiency $\eta$ (3) shows the ratio extent of channel information channel capacity bandwidth $R_{d}$ to information throughput capacity $C_{C}$, and frequency parameters expressed in terms of performance $\gamma$ (1) and energy efficiency $\beta$ (2):

$$
\eta=\frac{R_{\mathrm{d}}}{C_{\mathrm{C}}}=\frac{\gamma}{\log _{2}\left(1+\frac{\gamma}{\beta}\right)} .
$$

The amount of transmitted information is estimated via the performance indicator channel $R_{\mathrm{d}}$ (4), which according to Shannon's formula for a discrete communication channel depends on the source speed $V_{S}$ and bit error probability $p_{b}$ in the recipient's information:

$$
\underset{\left.\left.\mathrm{p}_{b}\right)\right) .}{R_{d}}=V_{S} \cdot\left(1+p_{b} \log _{2} \mathrm{p}_{b}+\left(1-\mathrm{p}_{b}\right) \log _{2}(1-\right.
$$

Information channel capacity is determined by the bandwidth of the communication channel $C_{c}$ (5) according to Shannon's formula for continuous communication channel with bandwidth $\Delta F$ :

$$
C_{\mathrm{H}}=\Delta F \cdot \log _{2}\left(1+h_{\text {прм }}^{2}\right),
$$

where energy parameter channel $h_{r x}^{2}(6)$ is defined as the ratio of signal power $E_{C}$ to the noise power spectral density $N_{0}$ at the receiver point:

$$
h_{r x}^{2}=\frac{E_{C}}{N_{0}}=\frac{P_{r x} \cdot T_{C}}{N_{0}}=\frac{P_{r x}}{N_{0} \cdot V_{C}},
$$

where $P_{r x}$ - the signal power at the receiving point, $T_{C}-$ symbol length, $V_{C}=\Delta F-$ symbol rate of communication channel.

\section{Development of analytical equations to describe the corrective abilities of LDPC codes}

The study foundation is to restore credibility benchmarks proposed to use ultra-long block LDPC codes class, as one of the most effective means of improving the information transmission reliability. LDPC codes length exceeds several thousand bits as opposed to common codes (e.g., BCH) with thousands of bits length blocks.

The first stage of equations development for ultralong LDPC codes is associated with the synthesis of optimal structures for a given LDPC code block length $n$, usually more than a million possible combinations (19) - (22).

$$
\begin{gathered}
r_{k}=1-\frac{W_{c}}{W_{r}}+\frac{W_{c}-1}{n}, \\
H=\left[\frac{\frac{H_{1}}{\pi_{1}\left(H_{1}\right)}}{\frac{\vdots}{\pi_{W_{C}-1}\left(H_{1}\right)}}\right], \\
H=\left[A \mid I_{n-k}\right], \\
G=\left[I_{k} \mid-A^{T}\right],
\end{gathered}
$$

where $r_{k}$ - encoding rate, $H$ - verifying matrix of LDPC code, $G$ - generating matrix of LDPC code, $W_{\mathrm{C}}-$ the number of ones in columns of matrix $H, W r$ - number of ones in a row of matrix $H, \pi_{i}\left(H_{1}\right)$-submatrices formed permutations column base submatrices, $I_{n-k}-$ single diagonal matrix.

Based on the established simulation model, the tens of thousands LDPC codes verifying matrices are generated. The best correcting ability value of LDPC codes is obtained by analyzing the generated matrices code length $d=2 t+1$ is found, where $t-$ a number of corrected bits in the code word for the lengths $n \leq 1000$ (Fig. 1). 


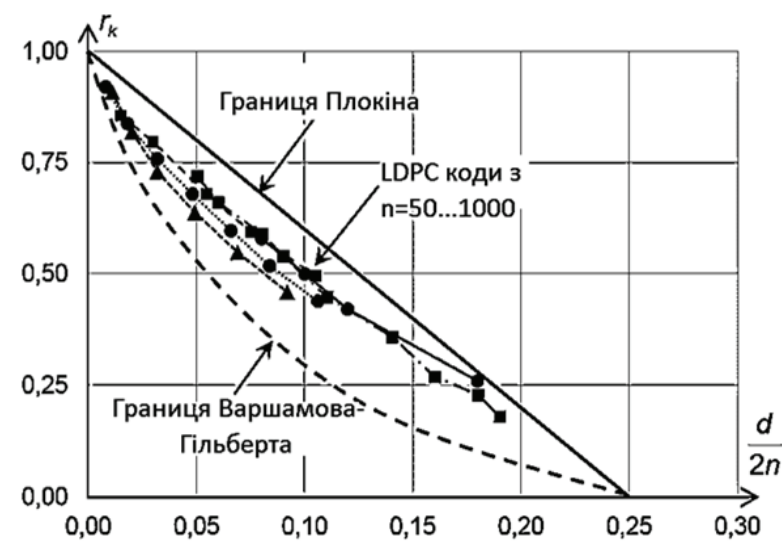

Fig. 1. The provisions of LDPC codes in the noise immunity codes boundaries existence

Fig. 1 shows that LDPC codes have better correction ability than other known noise immune codes, for example, BCH codes that exist on the VarshamovHilbert line.

The first phase result of equations development for ultra-long LDPC codes is the analytical dependence and equations that link LDPC corrective ability $t$ with code length $n$ at a given coding rate $r_{k}$ (23), (25):

$$
\begin{gathered}
t=\frac{n}{0,0004 n-8,2657} \ln \frac{r_{k}}{1,5354-0,085 \ln n}-1, \\
\Delta t_{\mathrm{err}}=\left|t_{\mathrm{exp}}-t_{\mathrm{anal}}\right|=0 \ldots 3 \text { bits, } \\
t=\frac{-\left(2 k_{1}+n k_{2}\right)-\sqrt{\left(2 k_{1}+n k_{2}\right)^{2}-4 k_{1}\left(k_{1}+n k_{2}+n^{2} k_{3}-n^{2} r_{k}\right)}}{2 k_{1}}, \\
(25) \\
k_{3}=-0,022 \ln n+1,1336, \\
\Delta t_{\text {err }}=\left|t_{\text {exp }}-t_{\text {anal }}\right|=3 \ldots 6 \text { bits, }
\end{gathered}
$$

where $k_{1}, k_{2}, k_{3}$ - coefficients that are the functions of the code length $n$. The results of analytical approximation and experimental results differ by no more than $0.3 \%$.

Thus, first time it became possible to determine the ability of correcting LDPC codes analytically for a given length of code length and encoding speed.

The second stage of research the correction abilities of LPDC codes is devoted to study LDPC codes with known parameters. These ultra-long LDPC codes are investigated with the length of the block more than 60,000 characters. Such ultra-long LDPC codes bring information encoding efficiency to the theoretical limit defined by Shannon's theorem for coding in channel with noise. The study used the original input receiving artificial false bits in the code word, and comparing the decoded codeword with the correct source code word.

Fig. 2 presents the research results of 64800 bits LDPC code block length correction abilities used in a standard DVB-T2/S2. The first time the analytical expression (28) is proposed for assessment the ultra-long LDPC codes corrected errors number $t$ on codeword length $n$ as a function of coding rate $r_{k}$ for a fixed length block: $n=64800$ :

$$
t=-39780 r_{k}^{3}+89947 r_{k}^{2}-76457 r_{k}+25431 .
$$

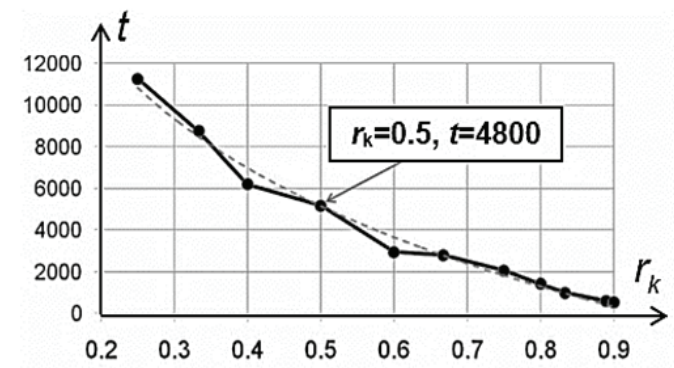

Fig. 2. LDPC code errors correction ability in fixed-length coding at different speeds

Thus, when LDPC code parameters are known, namely, the length of the block $n$ and the coding rate $r_{\mathrm{k}}$, it becames possible to determine the corrective capacity LDPC code $t$, bits.

The general result of the method development for ultra-long block LDPC codes control parameters are the defined code characteristics to ensure regular LDPC codes reliability using the found analytical equations and obtaining new scientific results related to the fact that the synthesized ultra-long LDPC codes parameters provide greater encoding rate (better information efficiency) to $12-20 \%$, even than some of the best known codes - BCH with length of the block of code to 1000 characters.

\section{The research of LDPC codes influence on information receiving reliability}

At the same time, to assess the efficiency of wireless information transmission systems, it's necessary to investigate the modulation-coding schemes (MCS), which combine the properties of multiposition modulation and noise immunity LDPC codes.

The modulation-coding scheme includes modulation (QAM-64, QAM-16 or QPSK) as a signal component, and noise immunity LDPC coding with specific parameters - as a code component. MCS is used in the study as a tool to increase rate and achieve the required reliability of information transmission.

Fig. 3 reflects the way of the MCS parameters research based on channel resources redistribution 
mechanisms: OFDM mode, modulation and LDPC coding. The method is supposed to use these tools for channel resources redistribution under certain power and frequency resources in communication channel. The method assumes the definition of the following parameters set:

- the best gain mode of the OFDM signal with $N$ OFDM subcarriers;

- appropriate MCS type;

- noise immunity encoding parameters: code words length $n$, encoding rate $r_{\mathrm{k}}$, code correcting capability $t$, which will ensure the reliability of reception.

Fig. 3 shows the reliability dynamics of the channel resources redistribution. Fig. 3 shows that for a certain modulation type in the single-carrier transmission (Fig. 3 point $\# 1 *$ ), focus mode OFDM (Fig. 3 point $\# 2^{*}$ ) accompanied by a significant deterioration in signal and power characteristics deteriorating reliability of receiving information. Optimum gain improves energy and increases channel reliability (Fig. 3 point $\# 3^{*}$ ). Noise immunity LDPC code with the right parameters compensates a transmission reliability (Fig. 3 point \#3). (29):

The task is formalized as noise immunity code search

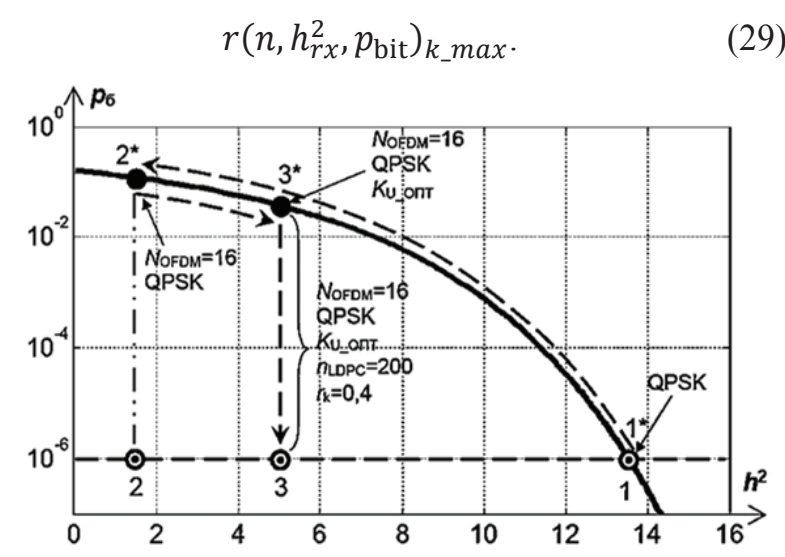

Fig. 3. MCS parameters research using LDPC coding and OFDM

Fig. 4 presents the algorithm of MCS parameters research to satisfy the required reliability.

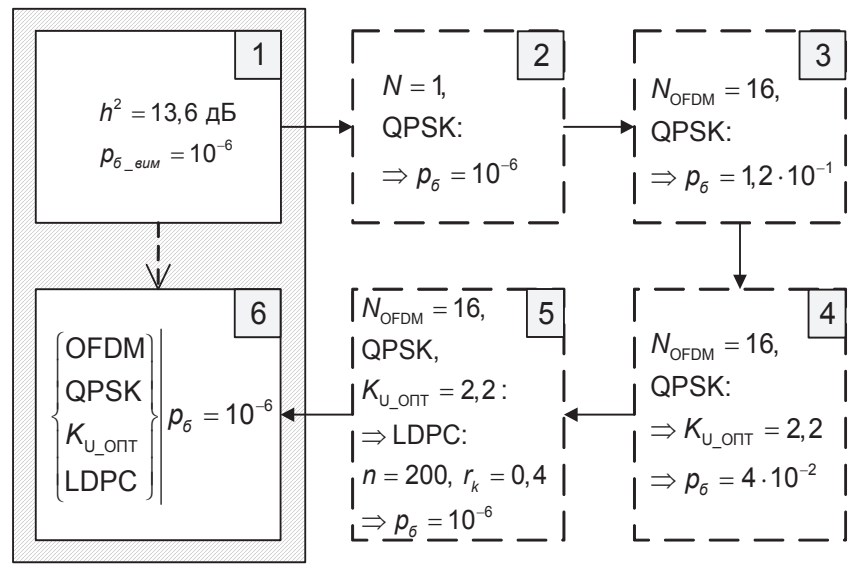

Fig. 4. The algorithm of MCS parameters research to satisfy the required reliability

\section{The LDPC influence on the communication channel effectiveness}

Fig. 5 presents an evaluation of information resources efficiency in the allocation of channel resources using OFDM, modulation and LDPC. Fig. 5 shows that the point $p_{\mathrm{b}}=10^{-7}$ defines the starting point for a singlecarrier mode, and the point $n=2000$ reflects the efficiency of resources reallocation when use LDPC coding. As shown in Fig. 5, information efficiency improved from 0.67 (point $10^{-7}$ ) to 0.73 (point $n=2000$ ), i.e. by $9 \%$. You can also see a gain in energy efficiency and a slight loss of frequency efficiency.

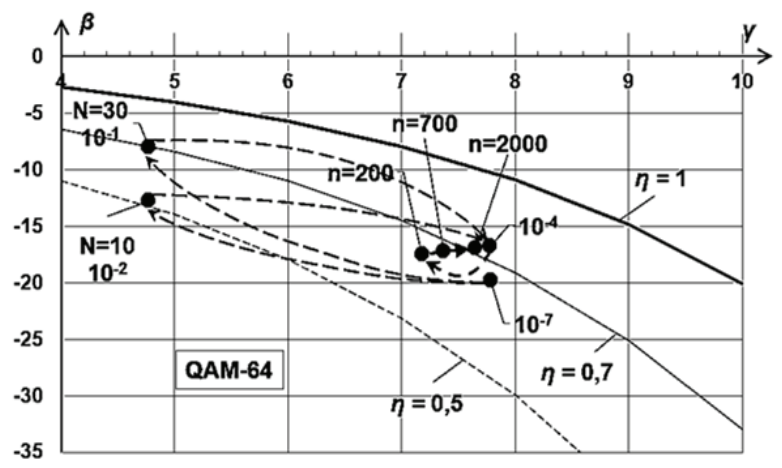

Fig. 5. The evaluation of information efficiency using the tools for channel resources reallocation

So, it's the first time the method is proposed for forming MCS with known parameters when using channel resources redistribution tools such as OFDM and LDPC for a given type of modulation, what increases information efficiency rate $\eta$ of wireless transmission systems by $9 . . .52 \%$, as shown in Fig. 6 . 


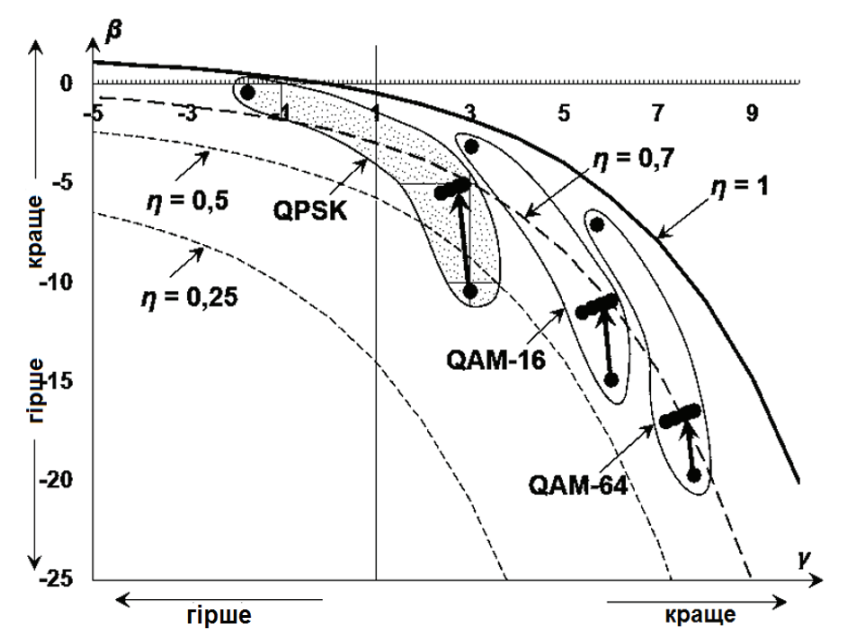

Fig. 6. Information efficiency evaluation for different MCS types

Thus, by the totality of the proposed methods of of wireless channel resources reallocation, it becomes possible to increase the efficiency of wireless information transmission systems by 9 ... 52\% through the use of modulation and noise immunity LDPC coding within the same channel dedicated resources compared with single-mode transmission.

\section{Conclusions}

The important scientific problem is solved in this work, - the construction and use of advanced wireless transmission systems with increasing information efficiency using LDPC coding. Stages of channel resources redistribution include LDPC, OFDM, modulation, described and presented in the information efficiency coordinates and transmission system performance.

The following main results obtained:

- The programmable simulation models to generate LDPC codes and errors number determining corrected LDPC codes with different parameters are developed. It's the first time the method is proposed of determining the ultra-long block LDPC codes to ensure the reliability characteristics specified in the channel with known parameters, characterized in that the analysis parameters LDPC code is implemented using the original statistical model and to evaluate corrective ability to code at a significant increase in the length of the block LDPC code,
- The LDPC codes influence on channel information efficiency is researched, and shown $9 . . .52 \%$ improvement.

\section{References}

1. T. Ohtsuki, "LDPC codes in communications and broadcasting," IEIC Trans. Commun., Vol. 90-B, no. 3, pp. 440-453, March 2007.

2. D. MacKay, Information Theory, Inference, and Learning Algorithms. Cambridge University Press, 2003.

3. L. Uryvsky, S. Osypchuk, "Analysis of corrective properties of ultra-long LDPC codes", Telecommunication Sciences, Volume 4, Number 1, 2013, pp. 21-26.

4. L. Uryvsky, S. Osypchuk, "Comparative analysis of LDPC and $\mathrm{BCH}$ codes error-correcting capabilities", Telecommunication Sciences, Volume 5, Number 1, 2014, pp. 5-9.

5. L. Uryvsky, S. Osypchuk, «THE ANALYTICAL DESCRIPTION OF REGULAR LDPC CODES CORRECTING ABILITY». Transport and Telecommunication, Latvia, ISSN 14076160, Vol. 15, no. 3, 2014, pp.177-184. (Scopus)

6. Uryvsky L.A. Research of statiproof LDPC codes / L.A. Uryvsky S.A. Osypchuk/ Science-intensive technologies in infocommunications: information processing, cybersecurity, informational struggle: Monograph / edited by V. M. Bezruk, V. V. Barannik. - Kh.: Publishing House Leader, 2017. - 600 p.

7. Osypchuk S. «The analytical description of regular LDPC codes error-correcting ability», 12th International Scientific Conference "Modern Problems of Radio Engineering, Telecommunications and Computer Science." TCSET'2014, February 25 - March 1, 2014. Lviv-Slavsko, Ukraine. p.76.

8. L. Uryvsky, S. Osypchuk, CODE RATE OF LDPC AND TRADITIONAL ANTINOISE CODES COMPARISON. - Eighth International Scientific Conference "Problems of Telecommunications", 2014 - p. 508-510.

9. L. Uryvsky, A. Moshynska, S. Osypchuk, "Algorithm of choice a multiposition keying in wireless system with LDPC coding", 22nd Telecommunications Forum TELFOR 2014, 2527 November 2014, Belgrade, Serbia. - pp. 399402. 
Уривський Л.О., Мошинска А.В., Осипчук С.О.

Підвищення інформаційної ефективності бездротових систем з використанням кодування Idpc

Проблематика. У статті проводиться дослідження впливу к параметрів кодів LDPC на інформаційну ефективність каналу зв'язку, яке вивчається в контексті формування сигнально-кодових конструкцій (СКК), при цьому переваги використання кодів LDPC в результаті досліджень оцінюються кількісно.

Мета досліджень. Метою даної роботи $є$ дослідження коригувальних здібностей кодів LDPC в сучасних телекомунікаційних системах та їх порівняння з іншими відомими кодами, що виправляють помилки, а також дослідження їх впливу на інформаційну ефективність каналів телекомунікаційної системи.

Методика реалізації. Алгоритм імітаційного моделювання реалізований як в Matlab, так і на мові Јava, що допомагає генерувати коригувальні матриці і дозволяє з'ясувати коригувальні можливості LDPC-кодів 3 різними наборами параметрів. Значна кількість експериментів дозволяє отримати статистику, яка виявляє максимальні і кращі коригувальні здатності кодів LDPC, що є метою застосування підходу до дослідження у вигляді імітаційного моделювання.

Результати досліджень. Розроблено програмовані імітаційні моделі для генерації кодів LDPC при різній кількості помилок, що визначають виправляють можливості кодів LDPC з різними параметрами. Вперше запропоновано метод визначення коригувальних здібностей наддовгих блокових кодів LDPC для забезпечення характеристик надійності, заданих для каналу з відомими параметрами. Метод відрізняється тим, що аналіз параметрів коду LDPC реалізований 3 використанням вихідної статистичної моделі для оцінки коригувальних здібностей коду при значному збільшенні довжини блочного коду LDPC. Також досліджено вплив кодів LDPC на інформаційну ефективність каналу. При цьому обгрунтовано збільшення показника інформаційної ефективності на 9 ...52\%.

Висновки. У цій роботі вирішується важлива наукова проблема - створення і використання сучасних систем безпроводової передачі з підвищеною інформаційної ефективністю на основі використання кодів класу LDPC. Етапи перерозподілу ресурсів каналу зв'язку включають в себе кодування LDPC, розподіл потоку по піднесучих OFDM, вибір виду модуляції, які представлені в координатах інформаційної ефективності та продуктивності системи передачі.

Ключові слова: інформаційна ефективність; ресурси каналу; коди з низькою щільністю і перевіркою на парність (LDPC); сигнально-кодові конструкції (СКК).

Урывский Л.О., Мошинская А.В., Осипчук С.А.

Повышение информационной эффективности беспроводных систем с использованием кодирования Idpc

Проблематика. В статье проводится исследование влияния параметров кодов LDPC на информационную эффективность канала связи, которое изучается в контексте формирования сигнально-кодовых конструкций (СКК), при этом преимущества использования кодов LDPC в результате исследований оцениваются количественно.

Цель исследований. Целью данной работы является исследование корректирующих способностей кодов LDPC в современных телекоммуникационных системах и их сравнение с другими известными кодами, исправляющими ошибки, а также исследование их влияния на информационную эффективность каналов телекоммуникационной системы.

Методика реализации. Алгоритм имитационного моделирования реализован как в Мatlab, так и на языке Јava, что помогает генерировать корректирующие матрицы и позволяет выяснить корректирующие возможности LDPC-кодов с различными наборами параметров. Множество экспериментов позволяет получить статистику, которая выявляет максимальные и лучшие корректирующие способности кодов LDPC, что является целью применения подхода к исследованию в виде имитационного моделирования.

Результаты исследований. Разработаны программируемые имитационные модели для генерации кодов LDPC при различном числе ошибок, определяющих исправляющие возможности кодов LDPC с различными параметрами. Впервые предложен метод определения корректирующих способностей сверхдлинных блочных кодов LDPC для обеспечения характеристик надежности, заданных для канала с известными параметрами. Метод отличается тем, что анализ параметров кода LDPC реализован с использованием исходной статистической модели для оценки корректирующих способностей кода при значительном увеличении длины блочного кода LDPC. Также исследовано влияние кодов LDPC на информационную эффективность канала. При этом обосновано увеличение показателя информационной эффективности на 9 ... 52\%.

Выводы. В этой работе решается важная научная проблема - создание и использование современных систем беспроводной передачи с повышенной информационной эффективностью на основе использования кодов класса LDPC. Этапы перераспределения ресурсов канала связи включают в себя кодирование LDPC, распределение потока по поднесущим OFDM, выбор вида модуляции, представленные в координатах информационной эффективности и производительности системы передачи.

Ключевые слова: информационная эффективность; ресурсы канала; коды с низкой плотностью и проверкой на четность (LDPC); сигнально-кодовые конструкции (CKK). 